\title{
PEMANFAATAN LAHAN PEKARANGAN MELALUI KEGIATAN PENGANEKARAGAMAN PANGAN LESTARI
}

\author{
Suhardi' ${ }^{1}$ Suwandi S. Sangadji ${ }^{\text {2, }}$ Hasna Ibrahim ${ }^{3,}$ Saiful Rachman \\ Universitas Khairun, Indonesia ${ }^{1}$ \\ Email:suhardiuim@gmail.com \\ Universitas Nuku, Indonesia ${ }^{2}$ \\ Email: suwandinukusangadji@gmail.com \\ Dinas Ketahanan Pangan Kota Tidore Kepulauan, Indonesia ${ }^{3}$ \\ Email:ibrahimhasna5@gmail.com \\ Universitas Nuku, Indonesia ${ }^{4}$ \\ Email: khosaifulrachman@gmail.com
}

\begin{abstract}
Abstrak
Pertumbuhan penduduk yang semakin tinggi menuntut pemenuhan penyediaan makanan dan perluasan daerah pemukiman. Hal ini akan berpengaruh terhadap peningkatan konversi lahan. Seiring dengan pertambahan penduduk dan alih fungsi lahan pertanian yang tidak akan pernah bisa dihentikan, maka berbagai upaya dilakukan untuk tetap mengusahakan tercapainya ketersediaan pangan. Upaya yang dimaksud yaitu dengan memberikan pendampingan dalam memanfaatkan lahan pekarangan masyarakat tani. Dengan kegiatan ini diharapkan masyarakat tani dapat memanfaatkan pekarangannya untuk bercocok tanam, guna memenuhi kebutuhan konsumsi sayur bagi keluarganya. Metode yang digunakan kegiatan ini adalah melakukan penyuluhan sekaligus pendampingan secara rutin dan berkala setiap bulan selama tiga bulan. Dari hasil pengabdian kepada masyarakat tersebut, diketahui bahwa masyarakat benar-benar memanfaatkan lahan pekarangan dengan baik. Hal ini dapat dilihat dari hasil produksi sayuran pada lahan pekarangan yang tidak hanya memenuhi kebutuhan konsumsi, melainkan sebagian dapat dijual ke pasar. Dari 30 rumah tangga yang melaksanakan kegiatan tersebut, semuanya berhasil memenuhi kebutuhan konsumsi sayuran seperti sawi, bayam, tomat dan cabe.
\end{abstract}

Kata Kunci: Pemanfaatan Lahan, Pekarangan, Pangan Lestari.

\section{Abstract}

Increasing population growth demands fulfillment of food supply and expansion of residential areas. This will have an effect on increasing land conversion. Along with population growth and the change in the function of agricultural land that can never be stopped, various efforts are made to keep trying to achieve food availability. The effort in question is to provide assistance in utilizing the farm community's land. With this activity, it is hoped that the farming community will be able to use their yards to grow crops, in order to meet the vegetable consumption needs of their families. The method used in this activity is to provide regular and periodic counseling as well as mentoring every month for three months. From the results of this community service, it is known that the community really makes good use of their yards. This can be seen from the results of vegetable production in yards that not only meet consumption needs, but some can be sold to the market. Of the 30 households that carried out the activity, all of them succeeded in meeting their consumption needs for vegetables such as mustard greens, spinach, tomatoes and chilies.

Keywords: Land Use, Yard, Sustainable Food.

\section{PENDAHULUAN}

Saat ini banyak sekali alih fungsi lahan terjadi, sementara disatu sisi lahan pertanian menjadi taruhannya. Hal ini sejalan dengan pendapat (Iqbal, 2007) dan 
(Dewi \& Rudiarto, 2013) bahwa akibat dari alih fungsi lahan pertanian yang dilakukan secara tidak terkendali maka, akan mengancam kapasitas penyediaan pangan dan dalam jangka panjang dapat menimbulkan kerugian secara sosial bahkan terjadi perubahan sosial ekonomi masyarakat hingga perubahan mata pencaharian. Kondisi kekinian diperparah dengan masa pandemi, yang mana dianjurkan untuk pembatasan aktifitas diluar rumah, sangat berpengaruh terhadap ketersediaan produksi pangan, sehingga optimalisasi lahan pekarangan sebagai sumber pangan keluarga (Thesiwati, 2020).

Di Indonesia terjadi penurunan luas lahan pertanian akibat dari alih fungsi lahan dimana pada tahung 2018 luas lahan tersisa 7,1 juta hektar. Penurunan angka ini terus merosot dibandingkan angka sebelumnya di tahun 2017 dengan luas lahan 7, 75 juta hektar (Isdiyana K. A., 2018). Lahan pertanian merupakan faktor produksi yang memiliki fungsi strategis bagi masyarakat Indonesia. Seiring dengan meningkatnya kebutuhan lahan, ketersediaan lahan terutama lahan pertanian yang relatif tetap menjadi semakin terancam. Konversi lahan pada intinya terjadi akibat adanya persaingan dalam pemanfaatan lahan antara sektor pertanian dan sektor non pertanian (Irawan,2008). Lahan pertanian memiliki banyak manfaat, baik secara ekonomi, sosial, dan lingkungan. Menurut Handoyo (2010), Secara ekonomi, lahan pertanian merupakan masukan paling penting bagi berlangsungnya proses produksi, kesempatan kerja, pendapatan, devisa dan sebagainya.

Pemanfaatan lahan pekarangan perlu dilakukan saat ini tatkala terjadinya konversi lahan pertanian. Pemanfaatan lahan pekarangan dirasa penting dilakukan untuk meningkatkan produksi sayuran sebagai sumber pangan dan pendapatan keluarga (Purwasih, 2019). Ketersediaan pangan sangat penting bagi kelangsungan hidup manusia sehingga pemanfaatan lahan pekarangan perlu dilakukan untuk mewujudkan ketahan pangan (Iswandi, Alwi, Nikoyan, \& Fyka, 2020). Selain itu, penguasaan teknologi dan inovasi perlu di kuasai oleh petani untuk menambah nilai guna produk dalam meningkatkan ekonomi keluarga selain sebagai kebutuhan akan pangan (Basuki, Suhardi S, \& Sangadji, 2020).

Menurut (Sukanata, Budirokhman, \& Nurmaulana, 2015) Kemandirian pangan dalam rumah tangga dapat terwujud apabila dimanfaatkannya lahan pekarangan rumah. Melalui pemberdayaan masyarakat Pekarangan Pangan Lestari dapat bermanfaat sebagai pemenuhan kebutuhan pangan keluarga, pengalaman diperoleh masyarakat baik dalam aspek ilmu dan bahan pangan yang bernuali gizi dan ekonomi tinggi (Sari \& Irawati, 2020).

Dari latar belakang dia atas, maka yang menjadi masalah adalah semakin berkurangnya produktivitas lahan pertanian, maka langkah apakah yang akan dilakukan untuk memenuhi kebutuhan pangan ditingkat keluarga petani. Sementara itu, pekarangan rumah petani juga belum dimanfaatkan secara optimal sebagai lahan tanaman pangan. Masalah ini dapat diselesaikan dengan adanya kegiatan pemberdayaan masyarakat dalam hal pemanfaatan lahan pekarangan dengan tema 
penganekaragaman pangan lestari. Kegiatan pendekatan pemberdayaan ini bertujuan memenuhi kebutuhan pangan masyarakat dengan segala keterbatasan yang dimiliki. (Siregar, et al. 2020) \& (Sangadji, et.al 2020). Dengan demikian kegiatan ini diharapkan dapat menambah pengetahuan kepada masyarakat kelurahan cobodoe dalam memanfaatkan pekarangannya untuk bercocok tanam, guna memenuhi kebutuhan pangan bagi keluarganya.

\section{METODE}

Metode yang digunakan kegiatan ini adalah melakukan penyuluhan sekaligus pendampingan secara rutin dan berkala setiap bulan selama tiga bulan. Pada minggu pertama dilaksanakan penyuluhan. Kegiatan penyuluhan semestinya menggunakan komunikasi yang efektif dan dapat menununjang keberhasilan kegiatan penyuluhan itu sendiri. Selain itu, yang lebih penting lagi adalah mengubah sikap dan perilaku masyarakat pertanian agar mereka tahu dan mau menerapkan informasi atau anjuran yang disampaikan oleh Penyuluh. Informasi yang disampaikan pada saat penyuluhan tidak sebatas teknik budidaya namun juga tentang strategi pemasaran komoditi hasil pertanian. Sebab tingginya keputusan pembelian produk pertanian dipengaruhi oleh faktor-faktor bauran pemasaran. (Karniyati, A., Suhardi, S., \& Sangadji, S. S., 2019), (Ngabalin, L. S., Sangadji, S. S., \& Suhardi, S., 2019), (Sangadji, S., Suhardi, S., \& Ali, C. P. M., 2019) dan (Sangadji, S. S., 2016). Kemudian pada minggu ke dua dilaksanakan pendampingan dalam persiapan baik saprodi maupun lahan hingga persemaian pada minggu ke empat. Pada bulan kedua dilaksanakan pemindahan atau penanaman ke bedeng dan polybag, hingga panen pada akhir bulan kedua. Selanjutnya pada bulan ketiga dilakukan pemantauan apakah kegiatan tersebut masih dilakukan atau tidak, jika dilakukan maka kegiatan dimaksud otomatis bermanfaat atau berdampak baik terhadap petani, tetapi jika tidak, maka akan ditanyakan kendalanya.

\section{HASIL DAN PEMBAHASAN}

Kegiatan dimulai dengan penentuan masyarakat sasaran, kemudian pengenalan kegiatan dimaksud kepada masyarakat sasaran melalui penyuluhan, termasuk semua bahan dan alat yang akan digunakan. Pengamatan terhadap pekarangan masyarakat sasaran adalah langkah selanjutnya, kemudian membentuk kelompok kerja. Setiap kelompok kerja dapat menggunakan sistem budidaya pertanian yang dikehendaki seperti sistem pertanian vertikultur. System pertanian vertikultur yang dipilih kelompok sangat menunjang kegiatan pemanfaatan pekarangan dimaksud. Berdasarkan hasil pengamatan pada lokasi kegiatan, diketahui bahwa komoditi yang dibudidayakan diantaranya chaisin, kangkung, cabe, tomat, kacang panjang, ketimun. 

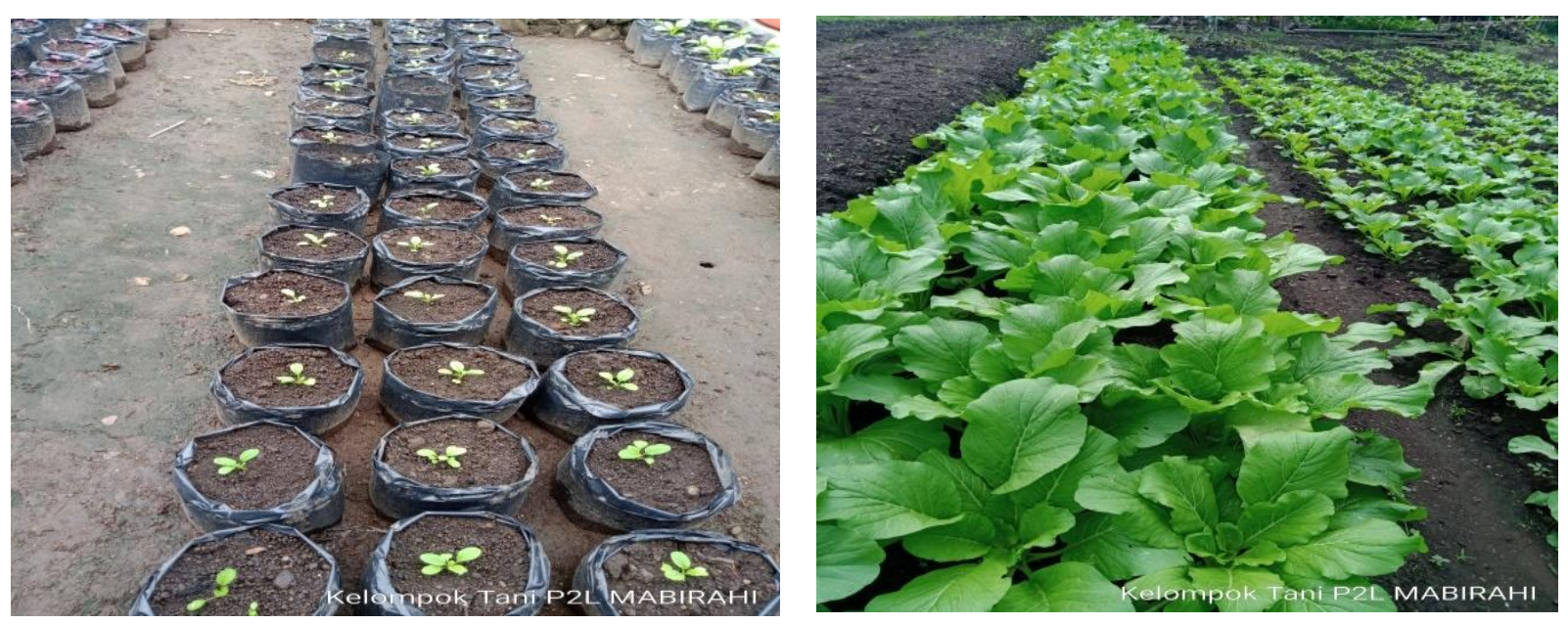

Gambar 1. Persemaian Caisin oleh Kelomok II

Gambar 2. Sayur Caisin Siap Panen
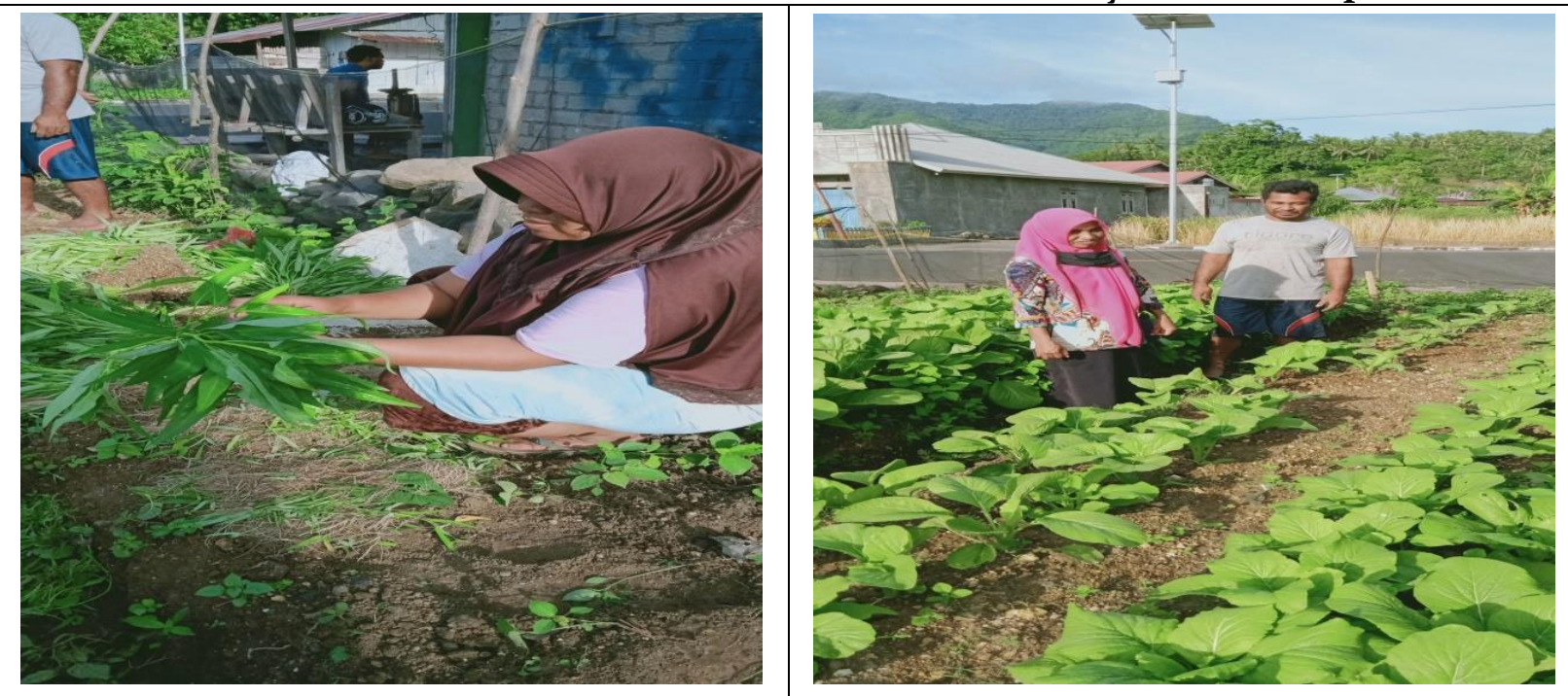

Gambar 3. Proses Panen Kangkung Cabut

Gambar 4. Pemantauan pasca kegiatan

Dari hasil kegiatan pengabdian kepada masyarakat yang dilaksanakan, memberikan dampak yang signifikan terhadap pemanfaatan lahan pekarangan oleh masyarakat. Bahkan kelompok tani yang memiliki pekarangan cukup luas, hasil budidaya aneka sayurannya dapat dijual pada beberapa tetangga disekitar rumah dan juga dijual ke pasar. Dari 30 rumah tangga yang melaksanakan kegiatan tersebut, semuanya berhasil memenuhi kebutuhan konsumsi sayur seperti kangkung cabut, tomat atau cabe dari pekarangannya masing-masing.

\section{KESIMPULAN}

Kesimpulan dari kegiatan pemberdayaan masyarakat dalam hal pemanfaatan lahan pekarangan melalui program penganekaragaman pangan lestari yaitu masyarakat Kelurahan Cobodoe mulai menyadari betapa pentingnya pemanfaatan lahan pekarangan ketika banyak sekali alih fungsi lahan terjadi dan melalui kegiatan ini 
setiap anggota kelompok tani dapat memenuhi kebutuhan konsumsi sayur sehari-hari dari pekarangannya masing-masing.

\section{REFERENSI}

Basu Swasta, Dharmesta dan Irawan, (2008) Manajemen Pemasaran Modern, Yogyakarta: Liberty.

Basuki, N., \& Sangadji, S. S. (2020). Pengelolaan Kelapa Terpadu Zero Waste Di Desa Lembah Asri Kecamatan Weda Selatan. Jurnal Abdimas Bina Bangsa, 1(2), 231-239.

Dewi, N. K., \& Rudiarto, I. (2013). Identifikasi Alih Fungsi Lahan Pertanian dan Kondisi Sosial Ekonomi Masyarakat Daerah Pinggiran di Kecamatan Gunungpati Kota Semarang. Jurnal Wilayah dan Lingkungan, 1(2), 175-188.

Handoyo, Eko dan Tijan, (2010). Model Pendidikan Karakter Berbasis Konservasi: Pengalaman Universitas Negri Semarang, Semarang: Universitas Negri Semarang dan Widya Karya.

Hadi, Sutrisno. 2001. Metodologi Research Jilid III. Yogyakarta: Andi Offset.

Iqbal, M. \& S. (2007). Strategi Pengendalian Alih Fungsi Lahan Pertanian Bertumpu Pada Partisipasi Masyarakat. Jurnal Analisis Kebijakan Pertanian, 5(2), 167-182.

Isdiyana K. A., B. K. H. (2018). Perlindungan Hukum terhadap Lahan Pertanian Akibat Terjadinya Alih Fungsi Lahan Di Indonesia. JU, 2(2), 122-130.

Iswandi, R. M., Alwi, L. O., Nikoyan, A., \& Fyka, S. A. (2020). Pemanfaatan Lahan Pekarangan Untuk Pertanian dan Perikanan Dalam Menunjang Ketahanan Pangan Rumah Tangga Masyarakat di Kelurahan Bungkutoko Kecamatan Nambo Kota Kendari. Jurnal Pengabdian Masyarakat Ilmu Terapan, 2(1), 1-6.

Karniyati, A., Suhardi, S., \& Sangadji, S. S. (2019). Peran Penyuluh Pertanian dalam Pemberdayaan Kelompok Tani Di Desa Ampera Kecamatan Oba Utara Kota Tidore Kepulauan. Jurnal Aksara Public, 3(2), 99-108.

Kementerian Pertanian. (2019). Petunjuk Pelaksanaan Pekarangan Pangan Lestari, Jakarta

Ngabalin, L. S., Sangadji, S. S., \& Suhardi, S. (2019). Pengaruh Penyuluhan Pertanian Terhadap Efektivitas Kelompok Tani Jaya di Desa Danar Kecamatan Kei-Kecil Timur Selatan Kabupaten Maluku Tenggara. Jurnal Aksara Public, 3(2), 71-84.

Purwasih, R. (2019). Pemanfaatan Lahan Pekarangan untuk Budi Daya Sayuran Secara Hidroponik di Kecamatan Sungailiat, Kabupaten Bangka, Provinsi Kepulauan Bangka Belitung. Agrokreatif: Jurnal Ilmiah Pengabdian Kepada Masyarakat, 5(3), 195-201.

Sangadji, S., Suhardi, S., \& Ali, C. P. M. (2019). Pengaruh Bauran Pemasaran terhadap Keputusan Pembelian Sagu Rasa pada Gabungan Kelompok Tani Tagafura di Kelurahan Jaya Kota Tidore Kepulauan. Optimal: Jurnal Ekonomi dan Kewirausahaan, 13(2), 142-157.

Sangadji, S. S. (2016). Analisis Pengambilan Keputusan Konsumen terhadap Pembelian Jus Belimbing Winner Perkasa Indonesia Unggul Di Kota Depok (Doctoral 
dissertation, Universitas Mecu Buana Jakarta).

Sangadji, S. S., Sari, D. C., Rozi, A., Condro, T., Simanjuntak, R., Sari, A. F., ... \& Hartati, E. K. (2020). The Power of Entrenprenuership.

Sari, S. D., \& Irawati, A. (2020). Pemberdayaan Masyarakat melalui P2L (Program Pekarangan Pangan Lestari ) sebagai Pemenuhan Hak Konstitusional Ketahanan Pangan. Jurnal Madiun, 2(2), 74-83.

Silitonga, H. P., Syamsuri, A. R., Halim, A., Haryani, D. S., Sangadji, S. S., \& Samad, A. (2020). Pemasaran" Hasil pemikiran dari Para Dosen Berbagai Perguruan Tinggi di Indonesia (Book Chapter-)" (No. h7p6v). Center for Open Science.

Sukanata, I. K., Budirokhman, D., \& Nurmaulana, A. (2015). Faktor-Faktor yang Mempengaruhi Pemanfaatan Lahan Pekarangan dalam Kegiatan Kawasan Rumah Pangan Lestari (Studi Kasus di KWT Dewi Srikandi Desa Cipanas Kecamatan Dukupuntang Kabupaten Cirebon). Jurnal Agrijati, 28(1), 1-16.

Thesiwati, A. S. (2020). Pemanfaatan Lahan Pekarangan Sebagai Pangan Lestari di Masa Covid-19. Jurnal Pengabdian Kepada Masyarakat, 3(2), 25-30. 